\section{Early Child}

Development

and Care
Early Child Development and Care

ISSN: 0300-4430 (Print) 1476-8275 (Online) Journal homepage: http://www.tandfonline.com/loi/gecd20

\title{
Civic action and play: examples from Maori, Aboriginal Australian and Latino communities
}

\author{
Jennifer Keys Adair, Louise Phillips, Jenny Ritchie \& Shubhi Sachdeva
}

To cite this article: Jennifer Keys Adair, Louise Phillips, Jenny Ritchie \& Shubhi Sachdeva (2017) Civic action and play: examples from Maori, Aboriginal Australian and Latino communities, Early Child Development and Care, 187:5-6, 798-811, DOI: 10.1080/03004430.2016.1237049

To link to this article: http://dx.doi.org/10.1080/03004430.2016.1237049

\section{曲 Published online: 07 Nov 2016.}

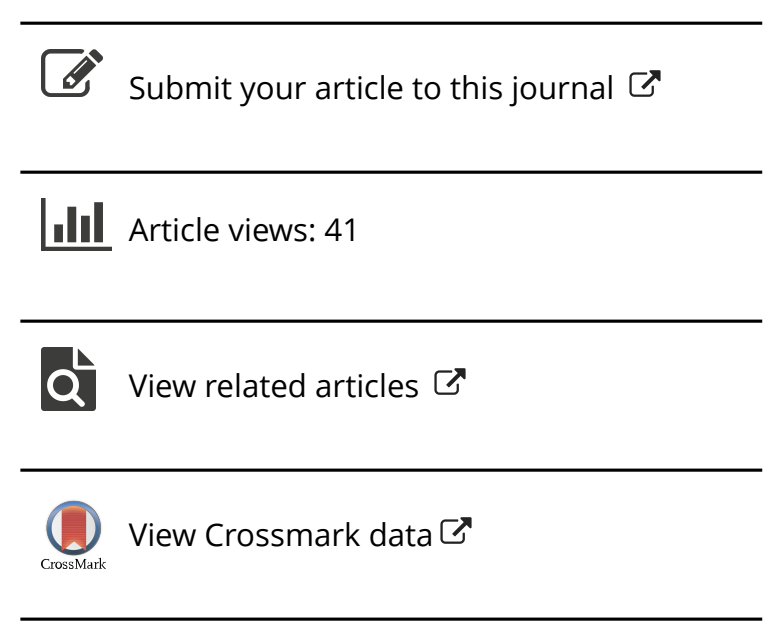




\title{
Civic action and play: examples from Maori, Aboriginal Australian and Latino communities
}

\author{
Jennifer Keys Adair ${ }^{a}$, Louise Phillips ${ }^{b}$, Jenny Ritchie ${ }^{c}$ and Shubhi Sachdeva ${ }^{a}$ \\ ${ }^{a}$ College of Education, The University of Texas at Austin, Austin, TX, USA; ${ }^{b}$ School of Education, The University of \\ Queensland, Brisbane, Queensland, Australia; 'School of Education, Victoria University of Wellington, Wellington, \\ New Zealand
}

\begin{abstract}
Using data from an international, comparative study of civic action in preschools in New Zealand, Australia and the US, we consider some of the types of civic action that are possible when time and space are offered for children to use their agency to initiate, work together and collectively pursue ideas and things that are important to the group. We use an example from each country and apply the work of Rancière and Arendt to think about collectivity as civic action in young children's schooling lives. Play, rather than an act itself, is positioned here as political time and space that make such civic action possible in the everyday lives of children. We argue here that play is the most common (and endangered) time and space in which children act for the collective.
\end{abstract}

\section{ARTICLE HISTORY}

Received 8 February 2016

Accepted 9 August 2016

\section{KEYWORDS}

Play; civic action; ethnography; early childhood education; cultural diversity; political agency

\section{Introduction}

While play is often associated with a type of action children do or a concept worth advocating for because of increasingly rigid early childhood educational programmes (Brown, 2010; Nicholson, Shimpi, \& Rabin, 2014), this article focuses on play as a political space that is free and unstructured. Play is seen here as a time and space in which children can initiate collective action (Pacini-Ketchabaw \& Nxumalo, 2015). Using data from an international, comparative project on civic action in preschools, we consider some of the types of civic action that are possible when time and space are offered for children to use their agency to initiate, work together and collectively pursue ideas and things that are important to the group. These acts, what we refer to as civic action, are collective acts. Play, rather than an act itself, is positioned here as merely making such a civic action possible in the everyday lives of children. Consider the following example that took place in Katoa Kindergarten in New Zealand.

A four-year-old boy, Manu, often initiates complex dramatic play scenarios, in which he usually plays the character of a dog named 'Toby'. One day (as was usual) several other children joined in, each determining their own roles. Keanu, Rōpata and Wiremu were all dogs. Charles decided he was a pussy-cat and Nikau was a puppy. Donald decided he would be a boy rather than an animal. A younger boy, Mikey, imitated the play at the periphery, without fully joining in. The boys initiated a fetching game, taking turns to retrieve small beanbags. Donald and Jenny (author) were assigned the role of being the throwers.

Soon, 'Toby' mimed that he had an injury, and suggested that there were Band-Aids in the imaginary cupboard. The game changed and the 'animals' now began supplying imaginary plasters (Band-Aids) and bringing them to Toby to restore his wounds. The game continued for some time, 
with activities often initiated by Manu (Toby), as the dogs and cats met their various needs for exercise and for food and water, which needed to be supplied from the imaginary kitchen.

Manu (Toby) initiated what became a collective enterprise. Children were welcome to enter the play even if they were not a dog or a cat. All of the children who wanted to participate, even at varying degrees, joined in without too much effort. In this game, children exercised their rangatiratanga (self-determination) and civic identity, acting as a group for the benefit of the group's overall health. All of the participants were able to contribute to the collective enterprise. They made decisions about who needed exercise first and who needed Band-Aids and how the fetching game would work. The dual honouring of both agency and participation is evident in this vignette. These elements of civic action - civic identity, civic deliberation, collective enterprise and shared concern - are part of everyday living of young children when they are able to use their agency to influence and even control how and what they are learning.

The collective action of the children being animals and then entertaining and caring for one another is not the development of civic action, but the actual doing of civic action. They are caring for one another. They are compromising, making collective decisions, identifying as a group, welcoming diversity and sharing concern. Using examples from children across the sites of our international, comparative ethnographic project - Civic Action and Learning with Young Children - we hope to demonstrate that seeing play as a political time and space rather than as an act of development allows us to recognize and value children's doing of civic action. Rather than seeing young children as developing civic action attributes, we will argue with examples and theory that children are doing civic action, that they are concerned and committed (right now) to collectivity. Play is the most common (and endangered) time and space in which children act for the collective.

\section{Play as a political space that supports the serious work of civic action}

Ethnographic research across the world describes how children organize play agendas, find play partners, resolve disputes, source and construct their own materials, and socialize younger children into the rules, goals and agendas, while adults are on the periphery or even out of sight (Hayashi \& Tobin, 2011; Bock, Gaskins, \& Lancy, 2008). We argue that it is in this free unstructured time (with reduced teacher direction) that children have agency to demonstrate and enact their civic capabilities and to respond to what is happening in a collective, rather than an individualistic, way.

The allocation of time and space where children have free choice is often labelled as play. When children govern themselves during this time and space, their acts are often seen as apolitical. And yet, children are actors within structures, institutions and communities that shape and are shaped by politics. Indeed, through the philosophical lens of Rancière (1991), even the exercise of an infant learning to express herself through language demonstrates her political agency, her intersubjective assertiveness, in articulating her intentions and communicating her feelings, desires, intentions and needs within the space she shares with others (Rancière, 2010b). A young child's early experimentation with communicating is viewed as reflecting a liberatory intent, described as 'stepping into language with all the force that is entailed in any political encounter of the emancipatory sort' (Bingham \& Biesta, 2010, p. 59).

Often children advocate for themselves and others in contexts labelled as 'play'. We suggest that the free choice times often known as 'play' can be seen as sites of political engagement. In accordance with Rancière's (2010a) definition, politics is about counting 'a part of those without a part' (p. 36). In the origins of citizenship and democracy in Ancient Greece, only wealthy men counted. Women, children and slaves were not included as citizens. And so, Rancière defines politics as the claims made to count those who are not counted, as witnessed through, for example, women's rights, race rights, working-class rights, children's rights, disability rights, asylum-seeker rights and lesbian, gay, bisexual, trans or intersex rights movements. Young children are typically not recognized as political beings, nor as bearers of politicalness. They are rarely (if ever) heard in public debate. Parents and early childhood educators listen to children, but it is unclear whether young children 
are engaged with as political beings. This study documented many examples of children acting as political beings, as those who actively seek to count 'a part of those without part', who may be excluded through ruling demarcations instated by educators, state or national policies, or by children who devise and assert their self-made rules. For example, we see children welcoming others into their play regardless of what animal or human form they entered in as and adapting games for newcomer participation as enacting civic agency and as acts of collective concern.

Also, part of being political is being able to initiate concern, change and collectivity as a citizen who can initiate action in the polis - a place of coexistence with others, many who may be unknown. Arendt's $(1958,1998)$ theory of human action offers a useful definition that is workable for young children. To Arendt, action is beginning something new in the world, public realm or polis, outside of our internal and personal spaces. Early childhood settings are, for many children, their first entry into the polis (a community of unknown others) (MacNaughton, 2007), thereby offering space for children to do civic action. The impulse for action comes from wanting to begin something new and emerges unexpectedly from what has happened before. Action differs from routine actions (such as eating, washing and cleaning), which consume most of our day as these are either work or labour. Actions do not exist in isolation: instead, 'they fall into an already existing web where their immediate consequences can be felt' (p. 184). In Arendt's theory, actions are recognized as affecting others, yet the effect is invariably not what the initiator intended because of conflicting wills and intentions in the web of human relationships in the polis. If an initiator tries to control how others respond to his or her action, or if individuals block others' opportunities to begin, agency is denied (Arendt, 1998; see also Biesta, 2010). Arendt advocated for worldly care for the public realm, where initiated actions are enacted with consideration for others. This understanding of action seemed workable in possibilities for young children's civic action through the recognition that young children would be motivated to begin something new in response to what they see, feel and hear in the early childhood setting.

By seeing play as a space for civic action, children are viewed as political through their capacity to initiate and respond to others in ways that support the initiatives of each other. Actions then involve responsive interaction with others through the interplay of doing, saying, listening and waiting. Such interactions welcome plurality and difference in that children's initiated actions 'are taken up by others in unprecedented, unpredictable and uncontrollable ways', as noted by Biesta (2010, p. 9) in his proposal of Arendt's theory of action for political coexistence in democratic education.

In this article, we combine Rancière and Arendt's ideas of political agency to notice children's influence, decisions and acts in the public sphere of their early childhood education and care settings. We see children's collective efforts to count those who are not always counted as civic action and we used this understanding to make sense of what children often do during play, particularly the initiation of acts for the common good. We recognize that it is the context of child-directed play that provides the greatest opportunity for young children to exercise civic action as political agency.

\section{Play, civic action and collectivity}

Our ideas about civic action stem from a communitarianism approach (Delanty, 2002) to defining and framing what civic action capabilities might be for young children. As a citizenship theory, communitarianism is focused on families, communities and cultural groups (rather than the state and economy), which form the polis that children have access to and are included in. Of particular interest in communitarianism is how people act in groups - group action. In our study of civic action and young children in different national, cultural and linguistic spaces, we sought to examine childinitiated group action in early childhood settings.

There are two specific principles of communitarianism (e.g. see Delanty, 2002; Etzioni, 1993; Monro, 2005) that guided our approach to civic action as a collective act by children. First, social cohesion and interrelatedness are developed through compassion, care and concern for fellow community members and responsibility to the community. For example, on numerous occasions we 
witnessed at all three sites young children comforting or helping another child so that they could rejoin the community activities. Second, social practices and values only have meaning within the historically developed social fabric of societies and cultures and are not isolated in just one moment. As witnessed at the Aboriginal Australian site, the cultural value and practice of 'looking out for your mob' are known and enacted by young children through getting extras (e.g. lolly (candy) or even a handful of sand) for your kin. This act of collectivity is as political as it is historical because young children are acting against decades, centuries even, of oppressive acts that try to destroy their affection and care for one another. Often in our work in all three countries, we saw practices of children's acts as responses to not just what was in their immediate classrooms or outdoor preschool spaces, but as responses to serious collective concerns that burden their families and communities.

\section{The civic action and learning study}

The Civic Action and Learning with Young Children study is a video-cued, comparative ethnographic project in three countries: New Zealand, Australia and the US. In each country, research teams have been working within an educational setting that serves communities who are politically underrepresented. In New Zealand, we are working with an early childhood education and care setting that serves Maori and Pacific Islander families. New Zealand is unique in our study because they have the least restricted space for children and they have the only bilingual/bicultural curriculum that attempts to privilege the values and language of Maori communities. In Australia, we are working with an Aboriginal Australian community formed a century ago through the government and missionaries' horrific forced relocation of 35 tribes and removal of children from their families, decimating dozens of languages and communities. In the US, we are working with a large city preschool that primarily serves Latina/o and African-American communities. The preschool teaches in both Spanish and English. Each of the three sites is explored in greater detail before each country's discussion of civic action and play. Included in these descriptions are the national/local understandings of play as well as the political standing of play in each country.

\section{Data collection in three countries}

Our study began with developing relationships with respected community members and educators at each site. We met with administrators, teachers and families to get to know them and their needs from us as researchers. We explained the study and sought their input on our data collection plan as well as how permission might be sought for observing and filming children. After the sites agreed to participate, we met with educators and families to seek permission, explain our study and answer questions.

After permission was granted, we spent eight to twelve months in each site collecting data through participant-observation and taking consistent field notes. All of the researchers participated in daily classroom life with children's activities and were available much like a teacher's assistant to help with whatever children or educators needed. Usually we watched children until invited to participate by them in a game, art project, dramatic activity or shared concern. We were eventually treated as part of the community and blended in easily to everyday life. When children and educators were familiar and comfortable enough with us in their space, we began to film and take pictures of daily civic action examples. We looked for children working together, including one another, having conflict, excluding others and caring for one another as well as caring for plants and animals. This resulted in substantial field notes, video recordings and photographic examples of children doing civic action.

While participating, observing and recording civic action in each site, we also interviewed the educators, community members and children using the video as a cue for discussion. For example, we showed the children video footage of themselves working together to get their responses. Children enjoyed watching films of themselves and their classmates. They also enjoyed watching films of children in other sites. We also showed educators scenes we filmed in their own classrooms for their 
feedback and suggestions, and to reassure them of what we were looking for. Educators in each country sought reassurance in different ways that we were getting what we hoped to. Showing them the films not only yielded a great deal of insight into practices, but also deepened relationships between the research team and the educator community in each space.

\section{Comparing approaches to play}

Towards the end of data collection in the US (the last site scheduled in the study), we noticed that all three sites in our study approached children and childhood somewhat differently and there were varying amounts of control and agency at each site for the children. These ideas connected to how much play was used as a term for children's actions as well as to label a specific time that was less structured. In New Zealand, for example, the term 'play' was not used nearly as much as in the other two sites. Katoa Kindergarten has only approximately 20 minutes of structured time in a 6-hour school day. Children are free to move inside or outside, enjoy whatever materials they wished and move around with classmates in any part of the space. The only exception is a small adult-sized kitchen on one side where teachers can freely go and eat food, get tea and socialize, and the teachers' office room. The sense of agency and movement extended to the educators as well. When educators described to us what children were doing, they hardly used the word play as if it was too general a term. They described children as doing art, work, caring, advocacy, resistance, developing empathy, working out problems and so forth.

In Australia, the preschool structure had a lot of open time labelled as 'play' where educators observed or engaged with the children. The educators viewed and advocated for play as a space for children to freely choose and direct activity. There were some structured times when children were asked to sit and pay attention, which engaged some children. Outside time happened multiple times a day, with the whole group required to relocate outside for adult supervision ratios to be maintained. Each age group had a separate, fenced outside space. Children's acts were often labelled as play in the children's presence, with teachers complimenting children on their play or letting children know that their play was too harsh.

The US site was the most structured space in our study. Children often gathered on 'the carpet' to listen to books read aloud by teachers, get instructions, learn about the day's schedule or practice letters and numbers. Children danced each day on the carpet. Children went outside as a class 1 or sometimes 2 times a day for a scheduled portion of time, as they shared the playground with 21 other classrooms and only a few classes could use the playground at a time. They had scheduled 'work time' each day in which children could move around the room and choose groups with ease. There were areas labelled as dramatic play, block area and computer area and there was also a book reading corner and an art area with lots of supplies. Teachers in the US used the word 'play' to talk in advocating ways about the need for play and for children to just explore and discover. When children were present, they used the word work to describe acts. For example, children would be complemented on how they were working, not on how they were playing. But all of the US teachers spoke to researchers about how important it was for children to play, describing acts they labelled to children as work.

Although there were many differences across the three sites, we did notice that during less or unstructured time when children could use their agency, there were acts children did every day at each site. Many of these acts were in pursuit of the common good. For the remainder of this article, we will describe children's efforts during unstructured time to initiate for the common good and try to make sense of their pursuits within the larger political and educational frameworks of each country and community.

\section{Play as constructed in the New Zealand early childhood context}

Play has historically been the predominant pedagogical approach in New Zealand early childhood care and education settings (May, 2009, 2013; Somerset, 1976). The New Zealand early childhood 
curriculum, Te Whäriki, recognizes that children 'learn through play' (New Zealand Ministry of Education, 1996, p. 82). The strand of 'exploration' states that children should experience an environment where 'their play is valued as meaningful learning and the importance of spontaneous play is recognized' (p. 15). By means of a focus on the curriculum principle of 'empowerment', children are encouraged to explore their environment, creating and acting on the own ideas, thereby developing their interests, knowledge and skills. In this context, 'Play activities in early childhood education invite rather than compel participation' (p. 40). Te Whäriki also states that 'There should be a recognition of Māori ways of knowing and making sense of the world and of respecting and appreciating the natural environment' (p. 82).

At Katoa Kindergarten, in Titahi Bay near Wellington, the capital city of New Zealand, the philosophy of the teachers is to allow children, ages 2-5 years, a great deal of freedom to determine their own agendas both indoors and in the large outside area. The outdoor spaces include some picnic-style tables, a sandpit, raised vegetable gardens, swings and flexible cubes, ladders and ramps that can be shifted in formation and operate as a climbing apparatus. Inside the kindergarten there are two food tables, several activity tables, books, puzzles and a large open space for block and dramatic play. Aside from two brief mat or circle times, one near the start of the day, and the other just before children leave to go home, children are free to move inside or out, to eat whenever they feel the need and to interact with whom or whatever they choose.

There are up to 40 kindergarten children attending on any 1 day, many of whom have Māori and/ or Pacific Islands' ancestry and affiliations. Currently, there are 10 pairs of siblings in attendance, as well as numerous others who are cousins. Research has shown that inviting under-two-year-olds to participate in kindergartens, traditionally oriented to three- and four-year-olds, has raised some challenges, and that having older siblings present can ameliorate some of these issues (Duncan \& Dalli, 2006). This is also consistent with Māori whānau practices of tuakana (older siblings) being expected to care for teina (younger siblings). On two days a week, additional younger children and parents are also present as part of a playgroup for the association's home-based programme that runs a morning session in conjunction with the kindergarten, this integrated service being part of the Whānau Manaaki kindergarten association's broader social equity initiatives (Whānau Manaaki, 2016). The six teachers, three women and three men, support the children in their endeavours, ensuring that they are observing the full spectrum of children's engagement as much as possible.

During our time of regular observations at Katoa, the teachers had a consistent and conscious focus on supporting children's social competence, scaffolding children to negotiate their social interactions. The current planning focus of the teachers is leadership, or rangatiratanga (self-determination). The morning mat-time is known as 'Kotahitanga time' (Kotahitanga means unity, solidarity, or collectivity). It is signalled by children acting as the kaikaranga (caller), standing at the edge of the doorway, calling out in te reo Māori (the Māori language) to the other children to come to the mat. The mat-time begins with a collective recital of the kindergarten whakatauki (proverb) which reflects the wisdom of Te Rauparaha, an ancestor of the local Māori tribe, Ngāti Toa. On a recent visit (January 2016), the teacher (Jared) who was leading Kotahitanga time asked the children 'Who will be the rangatira (chief/leader) to start off our whakatauki today?' Several children indicated that they were keen to take on this leadership role. One of these children, Miriama, was chosen by Jared, and she duly led the group into recitation of the whakatauki. Later in the mat-time, Jared encouraged the children to reflect on how they can let others know how they feel about something that is upsetting to them, and then to practise saying 'Stop it, I don't like it!' This pedagogical approach of freedom, accompanied by guidance and modelling, is consistent with Rancière's discussion of the role of teachers in 'making visible' the 'unequal equality' of our 'democratic' societies (Rancière, 2010b, pp. 8-9). 


\section{Learning to be Tuakana in New Zealand (collective caring)}

In relation to the civic action of social responsibility, children at this centre demonstrated caring for others on a daily basis during their engagement in the play-based programme. Because children ages 2-6 years were welcomed and shared the entire space at Katoa, the older and younger children (tuakana and teina), particularly siblings, spent a lot of time together. Teachers are very conscious of the role of the older siblings (tuakana) in offering secure attachment which regulates the sense of security of the younger sibling (teina). One two-year-old child named Anika greatly relied on her brother Donald for support and could usually be found in the vicinity of her brother, trailing behind him as he moved from one area to another. One afternoon Anika had hurt her toe and it was bleeding quite badly. Donald was summoned from where he had been playing outside, but after briefly checking on Anika, he returned to his outdoor preoccupation. One of the teachers continued to try and comfort her, but she was still crying inconsolably. A four-year-old girl Maria noticed Anika's distress and went to the child-height fridge/freezer that was available for children's use. She took out one of the ice-packs and brought it to the very upset Anika. Maria then sat alongside the teacher who was still holding Anika, and for quite some period of time leaned over towards Anika, talking softly to her, demonstrating care and aroha (love, concern).

More recently, Donald moved on from Katoa to start school. Several teachers explained to us that several other children at Katoa had taken over Donald's former role and were supporting Anika. Miriama, a three-year-old girl, along with several other girls had taken Anika under her wing, including her in their daily activities. This was having a reciprocal effect on Anika, helping her to learn to be a contributing part of the community. One morning Miriama and Anika were playing together outside. As they ran to the climbing frame, Miriama tripped and scraped her knee. The supervising teacher Jared suggested to Anika that she could go and get Miriama an icepack. Anika and Miriama then walked quietly inside and Anika retrieved an icepack from the fridge/freezer without any assistance, just as months earlier Maria had done for her. She gave the icepack to Merenia and then went and got a paper towel from the dispenser and handed it to Merenia. She bent over to help Merenia hold the paper-towel-wrapped icepack on her injured knee. This action lasted less than a minute before they tidied up together, putting the paper towel in the bin and ice pack back in the fridge/freezer. The only conversation took place at the end, when Anika asked Merenia 'You okay now?' The two girls then ran back outside to the climbing frame.

Anika, who previously had been cast as the teina and on the receiving end of care, has now assumed the role of tuakana, in caring for her friend. With no need for verbal agreements, the community helped Anika be a civic participant. There was trust and shared understanding that existed among the teachers and children to help Anika not just by doing things for her or comforting her, but giving her opportunities to do the comforting. Rancière's political agency ideals highlight the community value of 'being counted in' and what children can do and teach to others when they have agency to influence what they do as well as the space to move about freely and access useful materials. Anika is now part-taking in the political space of the early childhood play-based programme, able to initiate for the common good as many other children have done previously. The modelling of care by her brother, by Maria and Miriama, and the teachers has 'made visible' this aspect of social responsibility and agency in the service of others.

\section{Play as constructed in Australian early childhood education}

Play as a context for learning in Australia is generally well supported with play-based learning explicitly emphasized in the national early childhood curricula for 0-5-year-olds - Belonging, being and becoming: The Early Years Learning Framework for Australia (DEEWR, 2009). The introduction of a national standards school curriculum from 2010, and the growing attention to national (e.g. National Assessment Program - Literacy and Numeracy) and international (e.g. Program for International Student Assessment) standardized testing comparisons have produced a growing 'push down' 
effect foregrounding pressure to produce measurable academic achievement at younger and younger ages through didactic curriculum and pedagogy. Increased attention to standardized curriculum and assessment has meant that more early years teachers are moving away from play-based pedagogies to didactically address standardized content (Queensland Government Department of Education and Training and Griffith University, 2015). To campaign against these trends, play activism has also emerged among parents and educators wanting less structured experiences for children (e.g. see https://www.facebook.com/protectingchildhoodAER/).

In the Aboriginal community where we became part of the educational community of Buranba child care centre, play is understood as children freely exploring the environment and learning cultural values and practices. It is accepted community practice for children three years and older to independently wander the community. By 9-12 years of age, children have a home range of independent mobility of $7.8 \mathrm{sq} \mathrm{km}$ (Kreutz, 2014). The community is an entirely Aboriginal community of just under 2000, in which everyone knows each other. A central cultural value is shared care responsibility. Community members look out for each other, especially the young and the elders (Maddison, 2009). Children are expected to participate in this shared care. Veronica Ecenarro (a Bardi woman) explains that Aboriginal Australian adults trust older children to look after younger children and freely permit children to act out real-life situations that involve risks (Fasoli, Wunungmurra, Ecenarro, \& Fleet, 2010).

As a licensed child care centre, however, educators have to follow Australian child care regulations, standards and building codes to operate and receive government funding. Under these regulations, children's protection is foregrounded to the disservice of children's participation and agency. Children are confined to rooms and yards per year of age, separating family members for most of the day. Most of the educators do not interfere with children's play; rather, they stand back and are there when needed to comfort an injury and remind children of the imposed 'whitefella' boundaries and rules.

\section{Catching bees in Australia (collective venture)}

Outside one afternoon, all the children from toddlers to four-year-olds and visiting older school-age siblings/cousins were gathered in the same yard. Ezra and Talia noticed bees ${ }^{1}$ buzzing around a flowering shrub close to the boundary fence with the aged care facility. Ezra found a small plastic container and lid at the craft trolley outside one of the classrooms. He brought it back to the shrub with the intent to catch a bee. Talia stood beside him honouring interest in his initiative. Her younger sister Nelly and another two-year-old girl Mary (who had been crying for some time) also moved towards the shrub. Nelly offered lip gloss to Mary and she stopped crying. As the more experienced older sister, Talia supported and guided the application. Suddenly, this was interrupted by Ezra's highly animated excited leaps and yelps of 'I've got it' as he ran to tap Talia on the back to ensure she was part of the bee catching. The whole group followed around to the other side of the shrub, with Ezra and Talia saying 'my babybob' [bumblebee] and then squabbling 'no my babybob'. Then Ezra whacked Talia and she slightly cried. Ezra screamed vehemently 'my babybob'. Jarrah (a visiting school-aged cousin) lightly pushed Nelly from behind, and she whimpered. Jarrah tapped Ezra, who did not flinch as he and Talia were stealthily focused on following the bee as it moved around the shrub. Nelly started kicking the shrub and Mary started hitting the bush with a plastic wand. Talia stopped them by saying: 'No it's a bumblebee flower'. She returned to bee tracking.

Soon Ezra's eyes were fixed on a bee. He slowly leaned into the bush with the jar and the lid poised apart in opposing hands. Talia encouraged him with 'catch it'. At just the right moment he brought the jar and lid together and caught the bee. Talia exclaimed: 'Ezra got it!' Ezra then proudly admired his catch from all angles. Nelly looked in and Aiden came over to look too. He showed the bee in the jar to the others, then threaded his hand holding the jar through the fence so he could have a look without interruption. He told the others 'Don't touch', putting his other hand up to them. Then Ezra walked off with the bee in the jar, yelling 'Hey I got a bee' as he found his younger brother. He sat 
down on the grass to admire and observe the bee in the jar. Andrew and Talia looked for other bees in the bush. After some time, Ezra took the lid off the jar, emptying the bee onto the ground. Talia witnessed this. They both looked around to follow the bee and eventually moved back to the bush to locate another bee.

Ezra initiated bee catching in the community of children. Talia supported his venture; she did not block Ezra's bee-catching action. Ezra welcomed Talia into the action - a political conception of agency (Biesta, 2010). The supporting of each other's agency happens fluidly and frequently throughout the encounter. When Nelly applies lip gloss on crying Mary, Talia assists. And when Ezra catches the bee, others come to admire the catch.

Of course, everyone's agency was not welcomed and supported every time. For example, Ezra tried to control how others responded to his initiated action (bee catching) by whacking Talia when she claimed it was her bumblebee and stopping others from touching the jar. And Jarrah tried to interrupt the group action by pushing Nelly and Ezra. Yet these moments of blocking another's civic agency were brief interruptions. Welcoming one another into the action was a political act and this movement of agency between the children was fluid. The collective pursuit of the bee seemed to be more important than squabbles here and there. When Ezra and Talia squabbled over ownership of the bee, energy for this conflict was soon lost as attention to the cause (bee catching) overrode. In the end, Ezra even considered the agency of the bee and released it. The release of the bee passed by unremarkably as they promptly returned to the joint interest of bee catching.

Reading the encounter with Rancière's (2010a) understandings of politics, Ezra could be seen as the ruling in this context as the initiator of the action. He determined who was counted in and what actions were acceptable. He readily welcomed Talia (they share the same great grandmother) in as an accomplice who supported and encouraged, but her efforts to claim ownership of the bee were not acceptable and she was blocked with a whack. Ezra willingly showed his catch to others of all ages (especially seeking out his younger brother), while firmly setting the rule of no touching. Nelly and Talia advocated for the inclusion of Mary through offering the appeasement of the desirable lip gloss. And Jarrah sought to be included through attention-grabbing whacking, but stopped when he received no response from Ezra.

The cultural value of looking out for younger children and your kin shapes the enactment of who is counted in (the politics in play). From a very young age, these children know to look after anyone younger and their kin. For Aboriginal Australians, kinship commitments are wide, including a broad extended family of nans and pops, aunts, uncles, cousins and cousin's cousins. By learning from a very young age that you care for each other and you work together as a large extended family, community Elder, Sylvia, explains that 'you go together with your people and you'll win or you'll finish it that day and sort it out, 'cos you're not being a proper black fella unless you go in together'.

\section{Play as constructed in the US' preschool context}

At the start of institutional early childhood programmes in the US, play was conceptualized as a tool to help children develop skills and knowledge across physical, social, cognitive and emotional domains (Frost, Wortham, \& Reifel, 2008). Play was not necessarily for the pleasure of children, but more for the opportunity to learn through child-centred activities (Tobin, 2008). Play can be labelled and assessed as 'high-quality play' (Kessler \& Hauser, 2000; Meier, Engle, \& Taylor, 2010). Children are often taught how to play correctly (Paley, 2004). Teachers, to justify play in their classrooms, often have to learn how to assess play for learning and development (Subramanian, 2015). Regardless of diverse approaches and struggles with the concept of play, early education programmes are changing in the light of neo-liberal policies such as No Child Left Behind (Brown, 2009; Kane, 2015).

Approaches, access and ideas about play in the US are also cultural (Gaskins, 2014; Gupta, 2009), generational (Nicholson, Shimpi, Kurnik, Carducci, \& Jevgjovikj, 2014), gendered and sexualized (Blaise \& Taylor, 2012). Play intersects with racial, cultural and linguistic discrimination (Adair \& Doucet, 2014). This continues to be the case in the US as children have different levels of access 
to play inside and outside of classrooms, in the larger community and in their neighbourhoods (Copeland, Sherman, Kendeigh, Kalkwarf, \& Saelens, 2012; Miller \& Almon, 2009), increasingly dependent on the racial and economic characteristics of their families (Adair, 2014).

Lead by a Latina principal, Cielo Early Childhood Center serves primarily Mexican immigrant, African-American and Hispanic families centrally living in a large city. Children attend from ages three to five years. Children are assigned to age-differentiated classrooms of 12-16 children, so siblings are not usually in the same classroom. Each classroom has one lead teacher and one assistant teacher, except for the classroom serving special needs where there are two assistant teachers. Children attend school from 7:30 am to 2:30 pm and follow a daily routine of activities rotating from small group, outside time, work time, breakfast and lunch. Children are usually gathered together with a short book, song or set of instructions before moving on to the next activity. Days can include a visit to the garden, inside gym, science room or library. Worktime is the terminology used for the 45-minute period of time when children can move around the room and use the materials without much teacher direction. In other US classrooms, this time might be labelled as 'play' or 'free-time' or 'centres'. Educators at Garcia speak often about the importance of play for young children's development and learning.

\section{Fishing for letters in the US (collective governance)}

During centre time, Brittany picked up some wooden fishing poles from a bookcase. She brought the pole and a box of magnetic fish with letters painted on them to a nearby table. She spread the fish out on the table and began to catch them using the pole. Alvin saw this and got interested, picking up another fishing pole. He and another child, Diamond, joined in with Brittany trying to connect the magnet of the pole to the magnet on the lettered fish. Brittany tried to attach her pole to two fish and showed her efforts to us as well as to children around her. Alvin watched and then tried to pick up two as well. Noticing Alvin's attempts, Brittany quickly gathered all the fish and put them closer to her. Diamond saw this and said, 'Brittany, give some fish to Alvin, he doesn't have any!' Brittany looked at Diamond through the corner of her eye, pretending that she did not listen. She kept collecting the fish and pulling them towards her. Diamond again looked at her and said, 'Brittany, give Alvin some fish, it's not nice!' Brittany kept eyeing Diamond and Alvin but did not move the fish back to the centre part of the table.

Frustrated, Diamond started moving slowly towards the teacher all the while keeping an eye on Brittany. Brittany continued fishing but kept an eye on Diamond, who slowly inched towards the teacher, taking one step at a time. As soon as Diamond reached half way towards her teacher, Brittany, who was following her with her eyes, quickly moved all the fish that she had accumulated towards the centre of the table, where Alvin and Diamond could share. Diamond saw this and came back to the table.

Diamond noticed the injustice and unfairness in one person holding on to all the community resources. She spoke out against it and stood up for Alvin, arguing that all at the table should be counted as participants. When Brittany did not respond to her concern, she used nearby adults as leverage. Diamond could have run over to the teacher and encouraged the teacher to solve the problem. Alvin could have yelled out or followed Diamond to the teacher. Instead, Diamond walked slowly and purposely, giving Brittany time and space to influence what would happen. And Alvin watched and went along with the girls' responses. With Diamond and Alvin's support, Brittany had the opportunity to change the course of things without adult intervention. Diamond initiated action to create opportunity for Alvin and gave space for Brittany to make a decision that recognized others in the space. This all happened within a time and space that were not controlled by others (Arendt, 1998). The ability to solve communal problems without outsiders is an important skill for children of colour, who are often part of communities overly managed and controlled by outsiders in educational institutions (Delpit, 2006; Goldstein, 2008; Howard, 2006; Stipek, 2006) and beyond. 


\section{Theorizing civic action led by children}

In each of the three examples, there was attention and care of the collective. In many child development models, young children are described as acting in their self-interest rather than a collective good (See Corsaro, 2005 for a longer explanation of how children can be seen in social collectives, particularly peer cultures). In our examples, however, and through our two years of data collection, we have seen children routinely leave their activities, sacrifice something precious and share time and space in the pursuit of collective interest, not just an individual one. This included those who fought, hit, snatched and made trouble. When offered time and space to use their agency, children gave one another time and space to make decisions in the best interest of the collective. In all three countries, we saw countless examples of this phenomenon. Instead of doing whatever they wanted to with the space and time of play, young children in all three countries many times each day made decisions based on welcoming all to be counted and in support of a continuing sense of collectivity over individuality. Children, we are finding, have enormous potential for civic action and political will that is focused on the collective, rather than the individual. We see children use their agency towards civic action as an offer into the polis with consideration for others (Arendt, 1958, 1998).

As is the case with civic action and political agency, it does not mean children did not have conflict. In fact, conflict was often an opportunity to demonstrate the ability to do civic action, not just merely be in the process of developing civic action. As researchers, it was how we could see the collective direction of children's efforts. Play can be an opportunity to place ideals of the community in the pathway of the ideas of individual children, where children have to make decisions about inclusion and teachers have to make decisions about control and their role as a guide or authority figure (see Wisneski, 2011 for a classroom example of how play can challenge community ideals in early grade classrooms). Instead of giving in to individual agency, children in our three country studies seemed to give space and time to one another to make decisions that maintained the collective when they were given time and space to act. Preliminary data from our study suggest that adult intervention has a significant effect on the type and quantity of civic action children can do on a regular basis. There were many more examples of civic action in New Zealand and Australia, for example, than in the US because time and space directed by children are much less. Educators at Katoa (NZ) did not enter children's conflict or games unless invited and they usually did not enter conflict directly, but rather made suggestions to individual children who took them back into the conflict. They explained that children learn by trying to solve their problems themselves and through repeated failures to get what they want.

Adult intervention was different at Buranba and Cielo. Educators at Buranba (AU) offered specific directives and complements to children, as reminders of being caring community members. Educators often referred to the larger community or to kin when reminding children to share, be kind, not whack or help other children. They advocate for young children to be safe, to have good food, to be loved and to care for each other. The educators especially argue for these rights, because of the legacy of the intergenerational trauma of genocide and institutionalized racist abusive policies and practices. Educators at Cielo (US) helped children through conflict and disagreements, often moving from one side of the room to the other if they noticed a problem. Educators gave children words and phrases they could use in the conflict and then coached children through sharing what bothered them and making changes to avoid future conflict. They explained that children often need help solving problems and that young children who are victims or marginalized need support from them as adults. Educators in the US also explained that parents get really upset when children are hit, bit or pushed by other children, so they have to watch conflict closely.

While these differences require much more time and thought, it is important to share these differences in the context of civic action as children in different schools had different amounts of opportunities for young children to act collectively depending on how what educators thought was best for their learning experience as well as outside influences such as regulation or community values. As with previous studies, ideas about how much agency children should use in their learning and 
play was different at each site and these ideas seemed to impact the amount and type of civic action children could do more than say, developmental levels, school readiness measurements or children's backgrounds (see also Adair \& Colegrove, 2014). As Arendt $(1958,1998)$ explains, if an initiator tries to control how others respond to his or her action, or if individuals block others' opportunities to begin, agency is denied.

\section{Supporting civic action in and outside of play}

Children did civic action even in the most structured spaces, though often in smaller amounts and frequency. In the most structured of the three environments, we saw daily examples of children doing civic action, primarily acting towards the collective and counting all those who are not always counted. Play secured time and space (for children) for the public realm where initiated actions could be enacted with consideration for others.

The downside of pursuing play as a political space that makes civic action possible is that civic action possibilities may be limited to just that time and space, rather than interwoven throughout the day in many different types of situations. In settings where there is a limited allocation of time to play freely, these may be the only times that children can act for the collective, and thus there is a limit placed on when shared care, concern and action may be initiated and pursued. When children were responsible for more actions on their own or when they were able to have time and space to lead their own actions, they could better pursue civic action. Play outside or during work time was the main time and space in which children could act for the collective and think collectively. There are many more opportunities for children to initiate civic action. It should not be left only for 'play' time or 'free time'.

While play can be used as a signal for teachers to not intervene as much as usual and to give children more control and choice over what they do, it is also helpful to regard civic action as an important part of early childhood and make environmental, pedagogical and attitudinal changes that better accommodate children's capabilities to act civically, or collectively, to advocate for one another, work towards a shared interest, care for others as a group and make space for more people in activities.

\section{Note}

1. Native bees in Australia are stingless, and are culturally significant to Aboriginal Australians, with their honey valued as a prized gift and commodity.

\section{Disclosure statement}

No potential conflict of interest was reported by the authors.

\section{Funding}

This work was funded by the Spencer Foundation.

\section{Notes on contributors}

Jennifer Keys Adair, PhD is Associate Professor of Early Childhood Education at The University of Texas at Austin. Her areas of expertise include early childhood education, immigrant parent engagement, project-based learning and the importance of young children exploring racial and cultural differences.

Louise Phillips is a senior lecturer in arts and early years education at The University of Queensland, Australia. Her areas of expertise include storytelling, children's rights and citizenship and creative, perceptual and place-based pedagogies.

Jenny Ritchie lectures at Victoria University of Wellington, New Zealand. Her research and teaching focusses on early childhood care and education policy and pedagogies, and social, cultural and environmental justice issues.

Shubhi Sachdeva is a PhD student in early childhood education at the University of Texas at Austin. 


\section{References}

Adair, J. K. (2014). Agency and expanding capabilities in early grade classrooms: What it could mean for young children. Harvard Educational Review, 84(2), 217-241. doi:10.17763/haer.84.2.y46vh546h4112144

Adair, J. K., \& Colegrove, K. S. S. (2014). Communal agency and social development: Examples from first grade classrooms serving children of immigrants. Asia-Pacific Journal of Research in Early Childhood Education, 8(2), 69-91.

Adair, J. K., \& Doucet, F. (2014). The impact of race and culture on play in early childhood classrooms. In L. Brooker, M. Blaise, \& S. Edwards (Eds.), SAGE handbook of play and learning in early childhood (pp. 354-365). New York, NY: Russell Sage Foundation.

Arendt, H. (1958). The human condition. Chicago, IL: The University of Chicago Press.

Arendt, H. (1998). The human condition (2nd ed.). Chicago, IL: The University of Chicago Press.

Biesta, G. (2010). How to exist politically and learn from it: Hannah Arendt and the problem of democratic education. Teachers College Record, 112(10), 9-10. Retrieved from http://www.tcrecord.org/content.asp?contentid = 15744

Bingham, C., \& Biesta, G. J. J. (2010). Jacques Rancière: Education, truth, emancipation. London: Continuum.

Blaise, M., \& Taylor, A. (2012). Using queer theory to rethink gender equity in early childhood education. YC: Young Children, 67(1), 88-98.

Bock, J., Gaskins, S., \& Lancy, D. F. (2008). A four-field anthropology of childhood. Anthropology News, 4, 391-420.

Brown, C. P. (2009). Confronting the contradictions: A case study of early childhood teacher development in neoliberal times. Contemporary Issues in Early Childhood, 10(3), 240-259. doi:10.2304/ciec.2009.10.3.240

Brown, C. P. (2010). Children of reform: The impact of high-stakes education reform on preservice teachers. Journal of Teacher Education, 61(5), 477-491. doi:10.1177/0022487109352905

Copeland, S. N., Sherman, S., Kendeigh, C., Kalkwarf, H., \& Saelens, B. (2012). Societal values and policies may curtail preschool children's physical activity in child care centers. Pediatrics, 129(2), 265-274. doi:10.1542/peds.2011-2102

Corsaro, W. A. (2005). Collective action and agency in young children's peer cultures. In J. Qvortrup (Ed.), Studies in modern childhood: Society, agency and culture (pp. 231-247). Basingstok: Palgrave Macmillan.

Delanty, G. (2002). Communitarianism and citizenship. In E. F. Isin \& B. Turner (Eds.), Handbook of citizenship studies (pp. 161-174). London: Sage.

Delpit, L. D. (2006). Other people's children: Cultural conflict in the classroom. New York, NY: The New Press.

Department of Education, Employment and Workplace Relations (DEEWR). (2009). Belonging, being, becoming: The early years learning framework for Australia. Canberra: Commonwealth of Australia.

Duncan, J., \& Dalli, C. (2006). Under-3-year-olds in kindergarten: Children's experiences and teachers' practices: Summary report. Wellington: Teaching and Learning Research Initiative.

Etzioni, A. (1993). The spirit of community: Rights, responsibilities, and the communitarian agenda. New York, NY: Crown.

Fasoli, L., Wunungmurra, A., Ecenarro, V., \& Fleet, A. (2010). Playing as becoming: Sharing Australian aboriginal voices on play. In M. Ebbeck \& M. Waniganayake (Eds.), Play in early childhood education: Learning in diverse contexts (pp. 215232). South Melbourne: Oxford.

Frost, J. L., Wortham, S. C., \& Reifel, R. S. (2008). Play and child development. Newark, NJ: Pearson/Merrill Prentice Hall.

Gaskins, S. (2014). Children's play as cultural activity. In L. Brooker, M. Glaise, \& S. Edwards (Eds.), The Sage handbook of play and learning in early childhood (pp. 31-42). London: Sage.

Goldstein, L. S. (2008). Teaching the standards is developmentally appropriate practice: Strategies for incorporating the sociopolitical dimension of DAP in early childhood teaching. Early Childhood Education Journal, 36(3), 253-260. doi:10. 1007/s10643-008-0268-x

Gupta, A. (2009). Vygotskian perspectives on using dramatic play to enhance children's development and balance creativity with structure in the early childhood classroom. Early Child Development and Care, 179(8), 1041-1054. doi:10. 1080/03004430701731654

Hayashi, A., \& Tobin, J. (2011). The Japanese preschool's pedagogy of peripheral participation. Ethos, 39(2), $139-164$. doi:10.1111/j.1548-1352.2011.01182.x

Howard, G. R. (2006). We can't teach what we don't know: White teachers, multiracial schools (2nd ed.). New York, NY: Teachers College Press.

Kane, N. (2015). The play-learning binary: US parents' perceptions on preschool play in a neoliberal age. Children \& Society, 30(4), 290-301. doi:10.1111/chso.12140

Kessler, S., \& Hauser, M. (2000). Critical pedagogy and the politics of play. In L. D. Soto. (Ed.), The politics of early childhood education (pp. 59-71). New York, NY: Peter Lang.

Kreutz, A. (2014). Children and the environment in an Australian indigenous community. Abingdon, OX: Routledge.

MacNaughton, G. (2007). Trials and transitions to citizenship: What really matters in early childhood education? Paper presented at the Dean's lecture series, Faculty of Education, University of Melbourne.

Maddison, S. (2009). Black politics: Inside the complexity of Aboriginal political culture. Crows Nest, NSW: Allen \& Unwin.

May, H. (2009). Politics in the playground: The world of early childhood in New Zealand (2nd ed.). Dunedin: Otago University Press.

May, H. (2013). The discovery of early childhood (2nd ed.). Wellington: NZCER Press. 
Meier, E., Engle, B., \& Taylor, B. (2010). Playing for keeps: Life and learning on a public school playground. New York, NY: Teachers College Press.

Miller, E., \& Almon, J. (2009). Crisis in the Kindergarten: Why children need to play in school. Education digest: Essential Readings Condensed for Quick Review, 75 (1), 42-45.

Monro, S. (2005). Gender politics: Citizenship, activism, and sexual diversity. London: Pluto.

New Zealand Ministry of Education. (1996). Te Whāriki. He whāriki mātauranga mō ngā mokopuna o Aotearoa: Early childhood curriculum. Wellington: Learning Media. Retrieved from http://www.education.govt.nz/early-childhood/ teaching-and-learning/ece-curriculum/te-whariki/

Nicholson, J., Shimpi, P. M., Kurnik, J., Carducci, C., \& Jevgjovikj, M. (2014). Listening to children's perspectives on play across the lifespan: Children's right to inform adults' discussions of contemporary play. International Journal of Play, 3(2), 136-156. doi:10.1080/21594937.2014.937963

Nicholson, J., Shimpi, P. M., \& Rabin, C. (2014). 'If I am not doing my own playing then I am not able to truly share the gift of play with children': Using poststructuralism and care ethics to examine future early childhood educators' relationships with play in adulthood. Early Child Development and Care, 184(8), 1192-1210. doi:10.1080/03004430.2013. 856894

Pacini-Ketchabaw, V., \& Nxumalo, F. (2015). Unruly raccoons and troubled educators: Nature/culture divides in a childcare centre. Environmental Humanities, 7(1), 151-168. doi:10.1215/22011919-3616380

Paley, V. G. (2004). A child's work: The importance of fantasy play. Chicago, IL: University of Chicago Press.

Queensland Government Department of Education and Training and Griffith University. (2015). Age-appropriate pedagogies for the early years of schooling: Foundation paper. Brisbane: Queensland Government Department of Education and Training. Retrieved from http://deta.qld.gov.au/earlychildhood/pdfs/foundation-paper.pdf

Rancière, J. (1991). The ignorant schoolmaster: Five lessons in intellectual emancipation (K. Ross, Trans.). Stanford, CA: Stanford University Press.

Rancière, J. (2010a). Dissensus. London: Continuum.

Rancière, J. (2010b). On ignorant schoolmasters. In C. Bingham \& G. Biesta (Eds.), Jacques Rancière: Education, truth, empacipation (pp. 1-24). London: Continuum.

Somerset, G. (1976). Vital play in early childhood. Auckland: Playcentre Association.

Stipek, D. (2006). No child left behind comes to preschool. The Elementary School Journal, 106(5), 455-466. doi:10.1086/ 505440

Subramanian, M. (2015). Rethinking play: A postcolonial feminist critique of international early childhood education policy. International Journal of Educational Development, 45, 161-168. doi:10.1016/j.jjedudev.2015.10.001

Tobin, J. J. (Ed.). (2008). Making a place for pleasure in early childhood education. New Haven: Yale University Press.

Whānau Manaaki. (2016). Kindergarten. Education and care. Whānau Manaaki. Our vision. Wellington: Whānau Manaaki. Retrieved from http://www.wmkindergartens.org.nz/About-Us/Our-vision-__.928

Wisneski, D. B. (2011). Complicating the role of play in building classroom community. In C. Lobman \& B. E. O'Neill (Eds.), Play and performance: Play \& culture studies volume 11 (pp. 33-58). New York, NY: University Press of America. 